\title{
Marriage Regulation in Spain. Current Situation and Challenges
}

\author{
Dr. Carmen Garcimartín \\ University of a Coruña, Spain \\ Professor, Faculty of Law \\ E-mail: carmen.garcimartin@udc.es
}

Marriage has changed profoundly during years. The current definition of marriage in Spanish law has abandoned the pattern of a stable union of a man and a woman aimed to raise the next generation. Several problems arise from this departure; the most important ones are figuring out which are the constitutive elements of marriage according to the laws in force, and trying to build a consistent regulation of this relationship. The article includes a general overview of the history and the current regulation of marriage, and subsequently explores the main challenges to the regulation of marriage in the near future.

Keywords: marriage in Spain, family law.

\section{Contents}

Introduction ............................. 6

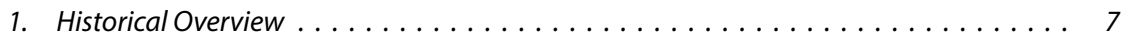

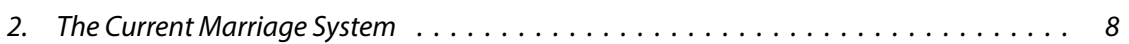

2.1. The Constitution .......................... 8

2.2. Other Norms . . . . . . . . . . . . . . . . . . . . . . . . . 10

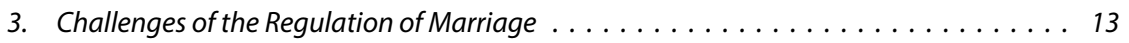

3.1. General Approach . . . . . . . . . . . . . . . . . . . . . . . 13

3.2. Defining the Essential Elements of Marriage . . . . . . . . . . . . . . . . 14

3.3. Should All Unions be Allowed into the Marriage Definition? . . . . . . . . . . . . 17

Summary. The Future of the Regulation of Marriage . . . . . . . . . . . . . . . . . 19

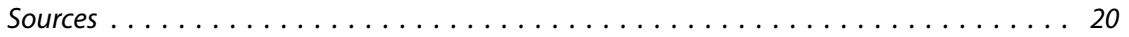

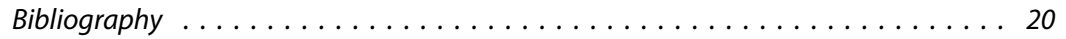

Normative Acts . . . . . . . . . . . . . . . . . . . . . . 20

Case Law ..................................... 20

Other Sources . . . . . . . . . . . . . . . . . . . . . . . . . . . . 20

\section{Introduction}

The institution of marriage for centuries has been a well-established relationship in Spain. Everybody was aware of its nature, aims, and its main characteristics. The law that regulated the marriage, either religious or civil (in the short periods during which the latter was allowed), corresponded to that general idea of the marital union: it was understood as a stable union of a man and a woman aimed 
at rearing the next generation. From a sociological point of view, marriage was the principal way to create a family. Surely, other kinds of unions - mainly cohabitation, which had not been preceded by marriage - were known in the country, but only the marital union enjoyed the legal status and social recognition.

Since the last decades of the XX century, major changes took place in Spain regarding the structure of the families. Family units became more diverse; factual unions and same-sex unions, among others, were socially accepted and legally recognized. The regulation of these other kinds of unions followed a specific pattern: instead of enacting a new regulation for each of these unions, taking into account its aims and characteristics, most of them were embedded in the marriage. As a consequence, the marriage gradually lost its clear shape and became a union that barely resembled the one of thirty or forty years ago. At this point, some authors wonder whether it makes sense to regulate marriage as a distinctive institution in the Spanish Civil Law. Others try to figure out the essential elements of the current legal marriage, as new challenges are still ahead.

The current article has three parts. The first one is a historical approach to the regulation of marriage in Spain. The second one explains the current situation, and the third one addresses the prospective of marriage in the Spanish law.

\section{Historical Overview}

The regulation of the marital relationship in Spain has directly descended from the Canon Law. Although Spanish Law belongs to the Roman-Germanic tradition, marriage has not retained many features from the Roman marriage - which is the antecedent of current factual unions, not marriage ${ }^{1}$.

The fall of the Roman Empire made Canon Law succeed in this field. After the Reformation, Europe split up into Protestant and Catholic countries, with Spain falling into the Catholic area. Thus, Catholicism became the official religion between 1492 and 1978. Hence, from the end of the Middle Ages until the end of the XIX century, Canon Law marriage was the only one regulated in Spain, and then the prevailing marriage until the end of the XX century ${ }^{2}$. There were two short breaks, with two laws of compulsory civil marriage ${ }^{3}$.

The first modern law of civil marriage was enacted in 1870 . It established that only the civil marriage would have civil effects, but it was ignored by most people who continued to marry according to the Canon Law ${ }^{4}$. To prompt the citizens to comply with the law, in 1872 the legislator approved a Decree that declared the children born within the Canon Law marriages illegitimate. Far from solving the problem, it worsened the situation, as thereby the number of illegitimate children in Spain increased. At that time, it was a major issue because of the succession

I would like to thank Jaime Vázquez García, Law and Business UDC student for his research assistance.

** Only literature available in English is cited in this article, although a number of articles in Spanish have been consulted for this work.

1 Nonetheless, the modifications of the regulation of the marital union in the latest years have introduced nuances to the idea of marriage that was prevalent in the past.

2 In 1564, King Philip II ordered that the dispositions of the Council of Trent about marriage were published as Law of the country and in all territories dependent on the Spanish Kingdom.

3 Cfr. Martínez-Torrón, J. Religion and Law in Spain. $2^{\text {nd }}$ edition. The Netherlands: Wolters-Kluver, 2018, p. 233.

4 Actually, this law was a kind of replica of the regulation of Canon Law marriage. It maintained impediments such as sacred orders and the vow of chastity in a religious institute, and considered the marital union indissoluble. 
laws in force. This situation was resolved in 1875, when the Law of civil marriage was repealed and the children born within Canon Law marriages since 1872 were recognized as legitimate with retroactive effect.

A system known as "subsidiary civil marriage" was in force since 1875. It meant that Catholics should marry according to Canon Law, and those who did not belong to the Catholic Church, or had declared that they did not profess that religion, could celebrate a civil marriage. Besides, the decisions of ecclesiastical courts about the validity or nullity of marriages were granted civil effect.

The second attempt to implement a system of obligatory civil marriage took place during the Second Republic, in 1931, when for the first time ever, divorce was accepted as a way to dissolve the marital bond, to the point that it was formally recognized within the Spanish Constitution ${ }^{5}$, leading to the enactment of the Spanish Divorce Law during the following year (1932). However, the aforementioned law still required a "justified cause" in order for the divorce to be accepted ${ }^{6}$, and ended up being formally repelled in 1938, in the middle of a civil war that lasted from 1936 to 1939 . Once the war ended, there was a return to the system of subsidiary civil marriage that remained in force until the contemporary Spanish Constitution was enacted, on December 27, 1978, and the Civil Code was modified to be consistent with the Constitution ${ }^{7}$.

\section{The Current Marriage System}

\subsection{The Constitution}

The Spanish Constitution provides the framework for the regulation of marriage. It does not contain a definition of the marital relationship; it does not stipulate the marriage system that must be implemented, either ${ }^{8}$. As expected in the fundamental text of a juridical body, it solely encompasses the main features of marriage, leaving its regulation to the lawmakers. For the purposes of the current article, two main sections can be highlighted: Section 32 and Section 16.

Section 32 stipulates:

1. Man and woman have the right to contract matrimony with full legal equality.

2. The law shall regulate the forms of matrimony, the age and capacity for concluding it, the rights and duties of the spouses, causes for separation and dissolution and their effects.

5 Section 43 of the Spanish Constitution 1931: "Marriage is based on equal rights for both sexes, and may be dissolved by mutual dissent or at the request of either of the spouses with allegation in this case of just cause."

6 The grounds for divorce are contained in Section 3, and include bigamy, one of the spouses being charged with deprivation of liberty for over ten years; suffering a contagious and serious venereal disease acquired through sexual relations either outside of the marriage and after its celebration, or before it, had they been purposefully concealed from the other spouse at the time of concluding the marriage.

7 Law 30/1981, July 7, that modifies the Civil Code in matters of marriage, B.O.E. No. 181, July 30.

8 Marriage system, in this context, refers to the norms stipulating the kinds of marriages which are granted civil effects, and on what conditions it is done. 
Section 16 states:

1. Freedom of ideology, religion and worship is guaranteed to individuals and communities with no other restriction on their expression than may be necessary to maintain public order as protected by law.

2. No one may be compelled to make statements regarding his or her ideology, religion or beliefs.

3. There shall be no state religion. The public authorities shall take into account the religious beliefs of Spanish society and shall consequently maintain appropriate cooperation relations with the Catholic Church and other confessions.

Some elements pertaining to marriage can be deduced from these articles.

The mention of the "full legal equality" between the spouses in Section 32 could be rendered, nowadays, as an open door to same-sex marriages. However, it was not the particularly feasible rendering of this concept at the time when the Constitution was firstly enacted. The reference to the equality between men and women in the marital relationship refers to the unequal relationship between husband and wife that existed until a few years before the Constitution was approved. During that time, women were subjected to their spouses' will, to the point that they required their husbands' permission for a number of juridical acts.

The current Spanish Constitution interdicts such a difference of status, guaranteeing that the inequality which has existed until the previously mentioned era would not be permitted to continue by reflecting this commitment in the constitutional text ${ }^{9}$.

Nonetheless, a reference to the heterosexuality of marriage is given in order to better understand the subject at stake. The wording of Section 32 of the Constitution neither explicitly requires nor bans the same-sex marriage. This is quite understandable, given the time when the Constitution was enacted - only three years after ending of Franco regime. The same-sex marriage, as well as other relationships like polygamy or civil partnerships were not among the main concerns of the authors of the Constitution. Their attention was focussed instead on other topics like divorce (not allowed then) or the transition from a confessional to a secular marriage system.

The most important item to highlight is that Section 32 uses the words "man" and "woman" instead of "all persons", "all", "everyone", "citizens", "all citizens", "Spaniards", or "all Spaniards". This is the only Section that explicitly indicates the gender distinction, hence, it may be significant. The Constitutional Court understood it when stated, in 1994, that "[T] he heterosexual element of the marriage is consistent with the Constitution. Public authorities can grant advantages to the family constituted by a man and a woman in opposition to homosexual unions. It does not preclude the legislator from enacting a regime where homosexual partners may enjoy the same rights and legal advantages offered by marriage. [..] The union between persons of the same biological sex is neither a regulated juridical institution nor a constitutional right; on the contrary, marriage between man and woman is a constitutional right"10.

9 See, in this regard STC No. 198, Nov. 6, 2012, FJ 8. Available: http://hj.tribunalconstitucional.es/en/ Resolucion/Show/23106 [last viewed 04.20.2021].

10 STC No. 222, July 11, 1994. Available: http://hj.tribunalconstitucional.es/en/Resolucion/Show/16344 [last viewed 04.20.2021]. 
The same-sex marriage was recognized in Spain in $2005^{11}$, after a rigorous social debate and an appeal to the Constitutional Court ${ }^{12}$. The Court issued a ruling in 2012 where it tried to dismiss its previous interpretation by saying that Section 32.1 of the Constitution cannot be understood as the establishment of the heterosexual principle of marriage ${ }^{13}$. However, the Court added that it cannot be understood either to mean that the heterosexual-only option was excluded. It comes to the conclusion that considering marriage only as a heterosexual union, and not granting marital benefits to same-sex unions would be consistent with the Constitution, as it recognizes the same-sex marriage. In other words, it considers that there is no pre-legal definition of marriage; marriage will be interpreted by the legislator any given time.

Another sensitive issue, not solved by the Constitution, concerns the kind of marriage - civil or religious - which the Constitution accepts or favours. The Constitution does not impose a mandatory civil marriage. It is clear, pursuant to Section 16-2, that it prohibits the system of compulsory religious marriage or subsidiary civil marriage, as Spain is no longer a confessional state and its citizens cannot be obliged to pledge allegiance to its ideology or religion to obtain the benefits of the law. Certainly, Section 16 recognizes the freedom of religion, stipulating that the state must take into account the religious beliefs of the society, but it does not imply the recognition of religious marriages.

To sum up: the Spanish Constitution merely provides some negative clues as to which marriage systems are not acceptable in Spain. Other legislative sources must be considered on order to ascertain the characteristics of the current Spanish marriage system.

\subsection{Other Norms}

The Spanish Civil Code does not contain a definition of marriage. Instead, it relies on a universal idea of marriage, and regulates it. This way, Section 44 states that "Men and women are entitled to marry in accordance with the provisions of this Code. Marriage shall have the same requirements and effects when both prospective spouses are of the same or different genders." It continues with the requirements of consent, the impediments to marriage and the diverse forms of marriage.

The most important element of marriage, the consent, attracts little attention; only a short article (45) refers to this aspect, asserting that it is necessary for the constitution of a valid marriage, and it cannot be conditioned or in any other way limited ${ }^{14}$. Such consent, as the Spanish legal doctrine points out, lies within the premise that those who are going to marry must "have the ability to understand and want the act that is performed"15. The impediments are treated similarly - simply mentioned without any other explanation. On the contrary, the legislator pays much

11 Law 13/2005, of 1 July, amending the Civil Code concerning the right to marry, B.O.E. No. 273, Nov. $15,2005$.

12 Appeal of unconstitutionality No. 6864-2005, in relation to Law 13/2005, of 1 July, amending the Civil Code concerning the right to marry, B.O.E. No. 273, Nov. 15, 2005.

13 STC No. 198, Nov. 6, 2012, cit.

14 Section 45: "There shall be no marriage without matrimonial consent. Any condition, term or mode limiting consent shall be deemed not to have been written."

15 Ortega Gimenez, A. Back to the "Marriages of Convenience" in Spain. Commentary on the Judgments of the Provincial Court of Barcelona of November 19, 2019 and January 29, 2020. 
more attention to the form and the critical aspect of marriage (the end of either the marital bond or the community of life $)^{16}$.

The Civil Code regulates two possible ways to celebrate the civil marriage: in a civil form, before a public officer, a judge or a mayor, and in a religious form ${ }^{17}$. The requirements and the effects of the marriage, as well as the registration, are identical in all cases. The only difference lies in its celebration, which can be civil or religious.

The possibility of celebrating a religious marriage other than Catholic became open immediately after the Constitution. In 1980, the Law on Religious Freedom was enacted; Section 2 of the aforementioned law stipulated that religious freedom secures the right to hold religious marriage ceremonies ${ }^{18}$. In 1981, an amendment to the Civil Code permitted the celebration of marriage according to the rites of the religious communities that signed an agreement with the State or in the terms provided by the State legislation ${ }^{19}$. By means of the Agreements of 1992, Jewish, Evangelical and Islamic communities were allowed to celebrate marriages according to their rites ${ }^{20}$. Until recently, no recognition of other religious marriages had been established either through an agreement or through unilateral State legislation. In 2015, the Law on Non-Contentious Judicial Proceedings granted civil effects to the marriages celebrated according to the form of religious denominations with recognized "deep roots" in Spain ${ }^{21}$ : as of now, they are the Church of Jesus Christ of the Latter-Day Saints, Jehovah's Witnesses, Buddhists and Orthodox Churches ${ }^{22}$.

The position of the Canon Law marriage has been confusing since the commencement of the constitutional regime. The norms related to this type of marriage are scattered across different laws, and they are not always fully coherent, even within the same legal body (the Civil Code, for example). There has not been much litigation on this issue lately, but mostly because the parties at stake prefer a practical accommodation. This fact does not preclude indicating the unclear aspects in the regulation of the civil effects of Canon Law marriage.

To begin with, Spain signed an Agreement with the Holy See in 1979, where it was stated that "The State recognizes the civil effects of marriages celebrated according to the Canon Law. Canon law marriage is considered legal under civil law from the moment of the celebration. For full recognition of these effects, the marriage must be registered in the Civil Registry; this may be done with the presentation of the church certificate of the existence of the marriage." 23 These norms, however, have been further elaborated by the reforms of the Civil Code

16 I will not refer to the economic effects of marriage, and to the procedural aspect of this relationship. I will rather focus on the definition of marriage and the constitution of the marital relationship.

17 Section 59: "Matrimonial consent may be given in the form provided by a registered religious confession, in the terms agreed with the State or, in the absence thereof, in the terms provided by State legislation."

18 Organic Law 7/1980, July 5, of Religious Freedom, B.O.E. No. 177, July 24.

19 Law 30/1981, July 7, that modifies the Civil Code in matters of marriage, B.O.E. No. 181, July 30.

20 The Agreements with the Evangelical, Jewish and Islamic communities were approved respectively by Laws 24, 25 and 26/1992, November 10 (B.O.E. No. 272, November 12). Section 7 of the Agreements recognize the civil effects of marriages celebrated before the religious ministers (or equivalent) of these religions, yet registration on the Civil Registry is needed for the full recognition (erga omnes) of those effects.

21 Law 15/2015, July 2, on Non-Contentious Judicial Proceedings, B.O.E. No. 158, July 3.

22 On the contrary, marriages celebrated according to the Gipsy customs and traditions, are not recognized in Spain, although in this case, it is an ethnic, not a religious minority.

23 Agreement on Juridical Issues between the Spanish State and the Holy See, January 3, 1979, sect. VI. 
subsequent to the Agreement, despite the fact that the Agreement with the Holy See is an International Treaty, while the Civil Code is a State $\mathrm{Law}^{24}$.

Article 59 of the Civil Code, as already seen, stipulates that matrimonial consent may be given in the form provided by a registered religious confession, in the terms agreed with the State or, in the absence thereof, in the terms provided by State legislation. This article refers, in general, to religious marriages, without any reference to the special regulation of Canon Law marriages. However, Article 60 states that a marriage performed in accordance with the provisions of Canon Law or in any of the religious forms mentioned in the agreements between State and religious denominations shall have civil effects.

Thus, the Civil Code singles out Canon Law marriages among all other religious marriages; it suggests that non-Catholic religious marriages will obtain civil recognition only as forms of celebration, while canon law marriage would be a whole system of marriage recognized by the State. The nominal differentiation of canon law marriage, together with the expression in accordance with the norms [and not form] of Canon Law, supports this interpretation; therefore, all rules on this kind of marriage, not only those dealing with the form, would be recognized by the Spanish State. However, this article is not clear, instead, it is sufficiently ambiguous to raise doubts about its intended meaning and scope ${ }^{25}$.

In practice, Canon Law marriages are celebrated according to the norms of Canon Law. Nevertheless, they must fulfil the prescriptions of the Civil Code, as well. Otherwise, the registration in the Civil Registry (required to obtain the civil effects of the marriage recognized erga omnes) will be denied. The potential discordances, that is to say, valid Canon Law marriages that cannot be registered in a civil form, are very few: marriages with an impediment dispensed in the Catholic Church but not in the civil arena, and marriages of a catholic who is already part of a civil marital union.

In order to avoid conflicts, the Catholic Church requires a special license of the Bishop to celebrate the Catholic marriage in those cases, targeting to solve the controversy before the wedding, by way of asking for a civil dispensation in the first case, or breaking the previous civil union in the latter one ${ }^{26}$. Nonetheless, marriages celebrated without license would still be valid; thus, the problem in these cases would remain unsolved; however, to be fair, these are very unusual situations, and do not deserve much attention.

In short, it can be asserted that the marriage system in Spain conveys several types or kinds of marriage: civil marriage regulated by the Civil Code and celebrated in a civil form; civil marriage celebrated in a religious form other than Catholic; and Canon Law marriage, regulated by the Code of Canon Law, but to which norms of the Civil Code are also applied.

24 Regarding this, see Martínez-Torrón, J. Religion and Law in Spain, p. 236.

25 Ibid., pp. 236-237.

26 The impediment of age is a tricky one. The Canon Law allows marriage from 14 years of age for women and 16 - for men (cfr. canon 1083). However, the Spanish Conference of Bishops stated that, if the prospective spouses are below 18 years of age (the legal age for civil marriage), they should ask for authorization of the Bishop (cfr. Decreto General de 26 de noviembre de 1983). If the answer is positive, the Bishop would not grant a dispensation but a license. The rationale of this rule is that bishops cannot modify the Code of Canon Law, but may issue a prohibition in their countries, if they consider it expedient. 


\section{Challenges of the Regulation of Marriage}

\subsection{General Approach}

There is an urgent need for a profound consideration of marriage and its regulation in Spain. It is not only a problem of updating the laws or solving some minor problems. The rapid changes in society anticipate more challenges ahead; thus, the legislator should have a clear idea of marriage and why the State should (if it should) enact laws on marriage, especially given the key role legal certainty holds within the Spanish system, as the Vice-President of the Spanish Constitutional Court points out quite precisely: the principle of legal certainty, as set out in article 9-3 of the Spanish Constitution, prevents leaving the application of constitutional principles such as equality and freedom in the hands of individuals. Therefore, it is necessary to have legal rules regulating the family system. But changes occur so quickly and so deeply that once lawmakers decide to regulate this system (Article 9.2 CE), they immediately must decide what kind of legislation is best suited for this task"27.

Most of the big debates related to marriage that have taken place in Spain since the enactment of the Constitution have focused on particular elements of this relationship that were being amended or modified. The social reaction to these changes was not uniform. For instance, the introduction of divorce in 1981 brought about a harsh controversy in the Spanish society ${ }^{28}$. Several decades later, in 2005, the approval of same-sex marriage triggered a similar conflict. Indeed, there have been other amendments that did not have a great impact in the social arena, although they also affected the structure of marriage. That is the case of the suppression of the impediment of impotence (marriage ceases to have a sexual content in its definition $)^{29}$ or the introduction of non-fault divorce (stability no longer is a target of the relationship) ${ }^{30}$.

The regulation of marriage has a moral and ideological content. That is why some modifications launch such a big controversy. Despite the greater or lesser juridical relevance of the amendments to that regulation, only two opposed stances on marriage lie in the debates about this relationship. The absence or presence of social conflict can be traced back to how the amendment could entail any changes to the core of those stances. The first of them considers that marriage is a pre-legal relationship, with some constitutive elements that define it: it is viewed as a union between a man and a woman in order to establish a stable community of life aimed at rearing the next generation. This specific kind of union has existed in some form in all known societies, since it corresponds to the social nature that characterizes human beings. Consequently, this trend argues that those particular features of the

${ }^{27}$ Roca Trias, E. Family Law as a Right to Freedoms: The Case of Same-Sex Marriage in Spain. International Journal of Law, Policy and the Family, No. 31, 2017, p. 80. She states that "My impression is that neither lawmakers nor their advisors are aware of what they have to deal with and even less of the role judges play in the whole system, since their role is far more limited as is clearly outlined in Article 117.11 of the Spanish Constitution, according to which judges are subject 'exclusively' to the rule of law, which means that formally they do not play a decisive role in innovating the legal system, although they may do so when they adapt rules designed for outdated conditions, which are not very unlike despite seeming different on the surface". (Ibid.).

28 Law 30/1981, July 7, cit.

29 Ibid.

30 Law 15/2005, July 8, that amends the Civil Code and the Code of Civil Proceedings in matters of marriage and divorce, B.O.E. No. 163, July 9. 
definition of marriage are binding to lawmakers, and it is beyond the scope of public powers to change them because they are inherent to the marital relationship. Thus, the regulation of the marriage can change in some aspects but it must always respect its essential elements ${ }^{31}$.

The second stance on marriage regards this relationship as whatever the legislator decides it to be, without relying on any previous reality whatsoever. Although it may have retained a certain form for centuries, it was merely due to historical and cultural reasons, but there is nothing off limits for lawmakers when it comes to the regulation of marriage. Therefore, the marital relationship has the shape that the legislator decides at a certain time and place; that is, its definition may vary, as there are no essential elements of the relationship that would be offlimits to the legislative power: marriage is what the legislator says it is, according to the social demand - or the political interest of the public powers.

\subsection{Defining the Essential Elements of Marriage}

From the evolution of the marriage regulation in Spain we can infer that the contemporary Spanish legislators do not perceive marriage as a pre-legal institution. Historically - and ever since, it has firstly been regulated by positive law - marriage has been aimed at the procreation and education of the offspring. Other kinds of personal unions have been known, and even received legal recognition ${ }^{32}$, yet marriage enjoyed a special status due to its social function. In the last decades, marriage has gradually been deprived of the elements that have shaped it for centuries.

Currently, according to the law, marriage is a relationship with very indefinite outline. It is a union of two persons who must help and respect each other at least for three months ${ }^{33}$. Nothing else is required from a legal point of view. Undoubtedly, the union of a man and a woman with their offspring corresponds to this concept, but many other unions do, as well: two friends that share an apartment, despite the absence of sexual relations between them; two aged siblings living together so as to care and accompany each other; people who want a temporary relationship, and other unions not related at all to the pre-legal idea of marriage noted above. However, once the legislator departs from that idea of marriage, its regulation raises several challenges.

The first one is finding a distinctive element of marriage. The Spanish Constitutional Court issued a definition of marriage when it decided on same-sex marriage. Since the generation of children could not be the aim of marriage if samesex couples were allowed to marry, the Court had to identify another distinctive element of marriage. In the ruling, it stated that marriage is a "community of affection that generates a bond, or a society of reciprocal help between two people who have the same position within this institution, and who voluntarily decide to

31 To offer an example: a constitutive element of sale is the price that a person pays for something. This price can be satisfied in different ways, and the legislator can adopt measures to avoid fraud or malice in payments, or may favour one method over another, but he cannot revoke the payment of price without completely distorting the idea of what a sale is. Even more, if there is no price, there is no sale; it would be a loan, a gift, or something else, but definitively not a sale.

32 For example, concubinage was regulated in Spain in the Middle Ages. Cfr. https://dej.rae.es/lema/ barragan\%C3\%ADa. It is also well known, if we look beyond the country, that same-sex relationships were usual in some periods of the Roman and Greek Empires.

33 According to Sections 86 and 87 of the Civil Code, the spouses may divorce three months after the celebration of marriage. 
join in a common family life project, giving their consent about the rights and duties of the institution and expressing it through the formalities established in the system. Thus, the equality of the spouses, the free will to marry to the person of their own choice and the manifestation of that will are the essential notes of marriage" ${ }^{\text {" }}$.

The definition of marriage as a "community of affection" is problematic. The law regulates rights and duties, but it does not deal with affection, understood as a feeling, even in cases where the affection should be more obvious than in a marriage, as in parental authority. The free will of the spouses can be verified, whereas affection is difficult to grasp in the juridical field. In practice, marriage can be celebrated, and be valid, even if affection is absent, as far as the prospective spouses agree to live together and respect and help each other.

Nonetheless, the idea of the community of affection is not new within the Spanish law, as it was used to define quasi-marital unions. Before they were regulated, when the legislator wanted to take into account de facto unions that were similar to marriage, it referred to marriages and "similar relationships of affection". The problem was that marriage was not defined by the affection, but by the will of the spouses and the aims of the union. This idea of community of affection tried to convey the aims of marriage (raising children in the most accurate environment and helping each other) depriving them of any reference to the generation. The issue here is that the community of affection depicted by the Constitutional Court may include some profiles as far from marriage as divorced couples, who still love each other (or at least they say so), have a common family project, freely stated, and hold an equal position in the relationship.

Besides the difficulty to find a distinctive element of marriage, those that still remain in the definition or in the content of the marital relationship may be queried, as well. Some uncertainties have been mentioned, but some others may arise. One of them is the establishment of a real community of life. It seems one of the few characteristics that remains in the current concept of marriage. However, the phenomenon of living apart together as an alternative way of stating a stable relationship would challenge that requirement. The rationale of those who defend this way of living is precisely maintaining the stability of the relationship by means of avoiding the difficulties that are incurred by living together.

A similar statement can be made about the open marriages, where the marriage does not preclude spouses from having sexual relations with other people. If they become not only socially acceptable, but legal, as well, the husband's presumption of paternity regulated in the Civil Code would need to be redesigned.

The absence of a clear concept of marriage in legislation elicits some incoherencies. It has already been mentioned with regard to the ban on marriage between close relatives, and more cases can be easily found. For example, since same-sex marriage was approved, the terms "wife" and "husband" were replaced by "spouse", or "progenitor A" and "progenitor B" when related to children. However, sometimes the law goes back to the "traditional" concept of marriage, using the term "husband". It happens when it regulates the presumption of paternity; the Civil Code says that children born after the wedding are presumed to be fathered by the husband $\mathrm{d}^{35}$. This presumption cannot operate in a same-sex marriage. It appears that the legislator thinks that most marriages will be a man-woman union, aimed to bear children, and that is the reason why the general regulation of marriage makes sense.

34 Cfr. STC No. 198, Nov. 6, 2012, cit., FJ 9.

35 Section 116 of the Civil Code. 
In this situation, the marriages of convenience lose most of its rationale; it is not worth faking a marriage, as celebrating a real marriage and divorcing after three months may appear less risky to obtain the expected benefit ${ }^{36}$. Although the Spanish Government tries hard to avoid this kind of marriage, acting in that way would not entail a proper fraud according to law, as the divorce is allowed without restrictions after three months of marriage, if both parties agree to it. Nevertheless, the phenomenon of marriages of convenience seems to be on the rise within the Spanish territory, thus, it deserves a few notes.

A marriage of convenience in Spain is understood in line with a common definition within all the European countries, as it was stated in the Council Resolution of December 4, 1997, on the measures to be adopted in the fight against fraudulent marriages ${ }^{37}$ : "the marriage of a national of a Member State or of a national of a third country regularly residing in a Member State with a thirdcountry national, for the sole purpose of circumventing the rules on entry and residence of third-country nationals and obtaining, for the third-country national, a permit residence or a residence permit in a Member State", and marriages of convenience are actually considered an abuse of rights in several European regulations ${ }^{38}$.

It appears rather striking that, although the marriages of convenience do fulfil both the consent and form requirements in order to become proper marriages, they are considered to be completely null and void both by the Spanish administrative institutions and the Spanish courts. In this sense, a resolution of the General Directorate of Registries and of the Notary (DGRN) of 31 January 2006 clearly states that this type of marriages "alter the meaning of the marriage institution since there is no true will to establish a marriage as a conjugal union and community of life between the spouses aimed at forming a family."

From the aforementioned resolution, it can be easily inferred that despite not being mentioned at all within the Spanish marital regulation, the cause for a marriage does play a fundamental role that may condition its own validity. The Spanish Supreme Court reaches the same conclusion when talking about marriages of convenience, asserting that the DGRN refers to the "cause" as a necessary element of marriage.

It is worth mentioning that the problems related to the marriage of convenience are expanding within the Spanish territory to "de facto unions"39, although the same solutions expect to be applied due to the similarities that they share.

36 The same opinion is shared the Spanish Supreme Court, which affirms "The differences between the valid marriage and the marriage of complacency are no longer clear, as of the 2005 legal reforms in the institution of marriage, which allow its dissolution due to divorce, at the request of only one of the spouses, once three months have passed from the celebration of the marriage, without any cause. This necessarily affects the content of the matrimonial consent, due to the difficulty of integrating it with specific conjugal duties, beyond its issuance in the manner required by law." (Vid: Spanish Supreme Court, Criminal Matters, Sentence 261/2017 of 6 Apr. 2017, Rec. 649/2016).

37 See Council of Europe, Resolution December 4, 1997 (97/ C 382/01).

38 For instance, The Article 35 "Abuse of rights" of Directive 2004/38/EC of the European Parliament and of the Council, of April 29, 2004, on the right of citizens of the Union and members of their families to move and reside freely in the territory of the Member States specifically mentions them as such: "Member States shall take the necessary measures to deny, terminate or withdraw any right conferred by this Directive in the event of abuse of rights or fraud, such as marriages of convenience [..."

39 Vid. Court of Soria, Judgement 62/2018 of June 25, 2018, Rec. 30/2018. 
Factual unions today pose several problems beyond those related to the legal fraud. The regulation of marriage is within the powers of the State, according to the Constitution $^{40}$. Nonetheless, all the autonomous communities have enacted their own laws that regulate de facto unions. Therefore, the possibilities of establishing a community of life in Spain vary depending on the territory where it is intended to be established. This is contrary to the equality of citizens who must have the same rights and duties in the entire territory of Spain. Therefore, it is the State who must decide on the types of union that will be recognized.

Unifying of the regime depends on the definition of marriage. However, if marriage has become an amorphous union, it makes no sense to maintain the regulation of the facto unions. It had a rationale when marriage kept most of their features. Those who did not want a stable, heterosexual union, aimed at caring for the next generation, could define another kind of union regulated by the State. Meanwhile, nowadays marriage provides for all those needs. Thus, there is no real need to multiply the regulations, when all of them fit in the regulation of marriage as it is now.

The regulation of other unions - under whatever name - is logical, if marriage is singled out in consideration of its aim. In this case, there would be marriage, with a very specific profile, and communities of life, that would be valid for any other unions that, respecting the basic principles of freedom, equality and public order, could be stated to satisfy the needs of affection, companionship, or any other.

\subsection{Should All Unions be Allowed into the Marriage Definition?}

Given that marriage is defined by the Constitutional Court as a community of affection established by free people, some restrictions to marriage lose their meaning. That is the case of the prohibition of marriage between close relatives or restriction of marriage to only two persons.

In the first case, that of the marriage between relatives, if the free will is the only requirement to marry, there is no clear reason for banning marriage between close relatives. Usually, a medical reason is alleged to when forbidding these unions: the offspring would have a high chance of carrying a genetic disease. However, on the one hand, sex is not a compulsory part of marriage, and therefore, siblings, for example, may decide not to bear children (or not to have sex at all), and they still might marry fulfilling all the legal requirements. On the other hand, medical reasons are not consistent with the general regulation of marriage; some people are aware that they may transmit a genetic disease, and they still can marry; their free will is the only grounds for this decision.

The same reasoning should apply to all kinds of unions. In fact, the only reason to maintain the prohibition or marrying close relatives would be that the Spanish legislator had the "traditional" marriage in mind as the model for marriage as such. Sexual relations between the consanguineous members of a nuclear family were not allowed in order to preserve the aim of the marital union, raising the new generation. The lack of sexual expectations makes the relationships among family

40 Section 149 of the Constitution. 
members completely different to those with outsiders, contributing to building an accurate environment for the growth and education of the children ${ }^{41}$.

Something similar could be argued regarding the so-called polyamorous unions. Polygamy, in its version of polyandry as a union of a man and several women (typical of some cultures, mainly under the Muslim area of influence) is usually despised and forbidden because it vulnerates the principle of equality and it is presumed to be imposed upon women against their free will. However, polyamory conveys a free will to have more than one partner; if they decide to have an equal position in the community, why should the law ban those unions? There is no clear answer, since the free will is now the supreme norm regulating the establishment of any kind of marital union.

Ultimately, marriage might even cease to be solely a union between human beings. The multispecies family, that which would include pets as members of the family, is making its way into the social field, and controversies already arise as to the juridical regime of animals in case of divorce. If pets are approved as members of the family, it will not be long until somebody demands to marry his or her dog, cat or whatever animal that person chooses to be his or her partner.

The problem is not whether these possibilities sound weird or resemble juridical fiction. The real problem will be finding a reason to deny entering into marriage to somebody who wants to state a union, once the free will is the only element that must be taken into account to create the marital bond. Even though the Constitutional Court labels the marriage as an institution, the lack of a permanent content of that institution diminishes the special protection it could carry. As the Vice-President of the Constitutional Court states, "the Constitution requires public authorities to provide social, economic, and legal protection for families" (Article $39.1 \mathrm{CE})$. However, from the earliest interpretations of constitutional rules, it has been highlighted that there is no constitutional concept to identify the type of family to which Article 39.1 CE refers. True, STC 222/1992 stepped beyond what we might call "traditional" interpretations and stated: "No constitutional problem would exist if the concept of family provided for in Article 39.1 of the Constitution were understood to refer exclusively to families based on marriage." Our Constitution has not equated the family to be protected with the families based on marriage, a conclusion imposed not only by the regulation that clearly differentiates between one institution and another (Articles 32 and 39). The aforementioned judgment states: "This protection is a consequence linked to the "social" character of our state (Articles 1.1 and 9.2) and therefore to the actual reality of the models of cohabitation existing in our society. Consequently, the meaning of these constitutional norms is not consistent with restricting the concept of families to matrimonial families, however relevant these may be in our culture", and adds: "Thus, there is no need to seek any necessary differentiation in article 39.1 between families based on marriage and those that are not, and nor was this differentiation mentioned by STC 184/1990." ${ }^{\prime 2}$

41 That is also the reason why some countries forbid marriage between persons who have lived in a close union, even though there is not any blood relationship among them. It is the case of step-parents, who are not allowed to marry their step-children, and children who are not siblings living together in a reconstituted family.

42 Roca Trias, E. Family Law as a Right to Freedoms, pp. 85-86. 


\section{Summary. The Future of the Regulation of Marriage}

The discussed issues lead us to an essential question: does marriage, as understood in the Spanish law, actually need a regulation at all? The law does not regulate personal relations (sexual relationships, or friendship, for example) unless there is a pronounced general interest thereof, as it happens with parenthood. Admittedly, marriage may generate economic effects and other obligations, like caring of the prospective offspring. However, children born out of wedlock enjoy the same protection as those born to a married couple ${ }^{43}$, hence, marriage adds almost nothing to the status of the latter. Regarding the economic effects, they might be regulated as a general community or society, without any specialty.

This situation led some authors to wonder whether regulation of marriage is really needed in the society of today. Families based on marriage used to be a cell of society. Despite the fact that the society is organized in families, the "family status" does not have the importance it has enjoyed for centuries. It is not the basic economic unit anymore; besides, parental rights and duties are recognized despite the bond that exists between the mother and the father, and the same can be said of other fields, like inheritance. Thus, if marriage still survives as a useful institution, it is because the majority of marriages fit the traditional definition, not because it is essential to the functioning of society. It appears that the public powers do not have a clear aim as to what marriage is or should be, although they appeal to the traditional idea of marriage when it is needed to maintain a certain measure or policy, as it happened with the marriages of convenience. In that case, the aforementioned Resolution of the DGRN 2006 refers to the community of life and the "specific aims of marriage" when no clear aims can be deduced from the current legal regulation of this kind of union.

If marriage is regulated and protected because of its benefits, a logical conclusion is that if the new idea of marriage depicted by the law does not necessarily provide for those benefits, the grounds for regulation and protection of that marriage may not be the same as those of traditional marriage. The developments of these past decades - non-fault divorce, same-sex marriage and others - have completely changed the shape and aims of the marital relationship. It still has to be demonstrated that all unions which now fall under the umbrella of civil marriage purport a benefit to society, because their aim is not to create and educate the new generation. Clearly, some individual unions can contribute to this goal, however, it has ceased to be an inalienable target of marriage. Then, if the marital unions are only self-fulfilling unions, without an outcome that may be of general interest, even if they are satisfactory for individual persons, why should public powers regulate them? There is no undisputable reason for the state to regulate these unions. Marriage appears as a relationship based on affection that demands economic benefits for no other special reason than two persons living together; something that good friends living together without having sex could demand, as well, following the same rationale. Besides, it is difficult to label a bond that does not have a real expectation of being sufficiently permanent to form the foundation of society. While the bond of true marriage is a bond, where both parties commit themselves permanently to certain rights and duties, it is not the same in the regulation of marriage currently in force, where one can opt out from that relationship so easily: it

\footnotetext{
43 Section 108 of the Civil Code.
} 
is a relationship existing today and dissolved tomorrow without much more trouble than returning an unwanted item bought in a store.

\section{Sources}

\section{Bibliography}

1. Martinez-Torrón, J. Religion and Law in Spain. $2^{\text {nd }}$ edition. The Netherlands: Wolters-Kluver, 2018.

2. Ortega Gimenez, A. Back to the "Marriages of Convenience" in Spain. Commentary on the Judgments of the Provincial Court of Barcelona of November 19, 2019 and January 29, 2020 [ResearchGate].

3. Roca Trias, E. Family Law as a Right to Freedoms: The Case of Same-Sex Marriage in Spain. International Journal of Law, Policy and the Family, No. 31, 2017, pp. 79-93.

\section{Normative Acts}

1. Spanish Civil Code, approved by Royal Decree July 24, 1889, Gaceta de Madrid No. 206, July 25. Available: https://www.boe.es/eli/es/rd/1889/07/24/(1)/con [last viewed 04.20.2021].

2. Spanish Constitution, 1931, Gaceta de Madrid No. 344, December 10. Available: https://www.boe. es/datos/pdfs/BOE/1931/344/A01578-01588.pdf [last viewed 04.20.2021].

3. Spanish Constitution, 1978 (in force), B.O.E. No. 311, December 29. Available: https://www.boe.es/ eli/es/c/1978/12/27/(1)/con [last viewed 04.20.2021].

4. Organic Law 7/1980, July 5, of Religious Freedom, B.O.E. No. 177, July 24. Available: https://www. boe.es/eli/es/lo/1980/07/05/7 [last viewed 04.20.2021].

5. Law 30/1981, July 7, that modifies the Civil Code in matters of marriage, B.O.E. No. 181, July 30. Available: https://www.boe.es/eli/es/1/1981/07/07/30 [last viewed 04.20.2021].

6. Laws 24, 25 and 26/1992, November 10, that approve the Agreements with the Evangelical, Jewish and Islamic communities, B.O.E. No. 272, November 12. Available: https://www.boe.es/eli/ es/1/1992/11/10/26 [last viewed 04.20.2021].

7. Law 13/2005, of 1 July, amending the Civil Code concerning the right to marry, B.O.E. No. 273, Nov. 15, 2005. Available: https://www.boe.es/eli/es/1/2005/07/01/13 [last viewed 04.20.2021].

8. Law 15/2005, July 8, that amends the Civil Code and the Code of Civil Proceedings in matters of marriage and divorce, B.O.E. No. 163, July 9. Available: https://www.boe.es/eli/es/1/2005/07/08/15 [last viewed 04.20.2021].

9. Law $15 / 2015$, July 2, on Non-Contentious Judicial Proceedings, B.O.E. No. 158, July 3 . Available: https://www.boe.es/eli/es/1/2015/07/02/15/con [last viewed 04.20.2021].

\section{Case Law}

1. Constitutional Court, Judgement No. 222, July 11, 1994. Available: http://hj.tribunalconstitucional. es/en/Resolucion/Show/16344 [last viewed 04.20.2021].

2. Constitutional Court, Judgement No. 198, Nov. 6, 2012. Available: http://hj.tribunalconstitucional. es/en/Resolucion/Show/23106 [last viewed 04.20.2021].

3. Appeal of unconstitutionality No. 6864-2005, in relation to Law 13/2005, of 1 July, amending the Civil Code concerning the right to marry, B.O.E. No. 273, Nov. 15, 2005.

4. Spanish Supreme Court, Criminal Matters, Sentence 261/2017 of 6 Apr. 2017, Rec. 649/2016.

5. Court of Soria, Judgement 62/2018 of June 25, 2018, Rec. 30/2018.

\section{Other Sources}

1. Council of Europe, Resolution of December 4, 1997 (97/C 382/01).

2. Directive 2004/38/EC of the European Parliament and of the Council. April 29, 2004. 